\title{
Environmental effect on yellow stem borer, Scirpophaga incertulas (Walker) and rice leaf folder, Cnaphalocrocis medinalis (Guenee) on rice crop
}

Authors Info

S. Zainab, B. Ram and R.N. Singh* Department of Entomology and Agricultural Zoology, Institute of Agricultural Sciences, Banaras Hindu University, Varanasi- 221 005, India

${ }^{*}$ Corresponding Author Email : singhrnacarology58@gmail.com

Key words

Abiotic factors,

Environmental effect,

Rice leaf folder,

Yellow stem borer

Publication Info

Paper received: 02.05.2015

Revised received: 01.03.2016

Re-revised received: 03.06.2016

Accepted: 12.07 .2016

\section{Abstract}

Aim : To study the impact of environmental factors on yellow stem borer (YSB) and rice leaf folder (RLF) on rice.

Methodology : An untreated rice plot of $100 \mathrm{~m}^{2}$ was studied to observe the impact of temperature, rainfall and relative humidity on seasonal abundance of yellow stem borer and rice leaf folder.

Results : Dead Heart (DH) incidence and White ear-head (WE) in YSB were negatively correlated with mean-temperature, positively correlated with relative humidity and showed significant positive correlation with rainfall. The percent incidence of RLF was significantly and negatively correlated with mean temperature, and positively correlated with mean relative humidity and total rainfall.

Interpretation : It was observed that abiotic factors play a crucial role in growth and survival of insects.

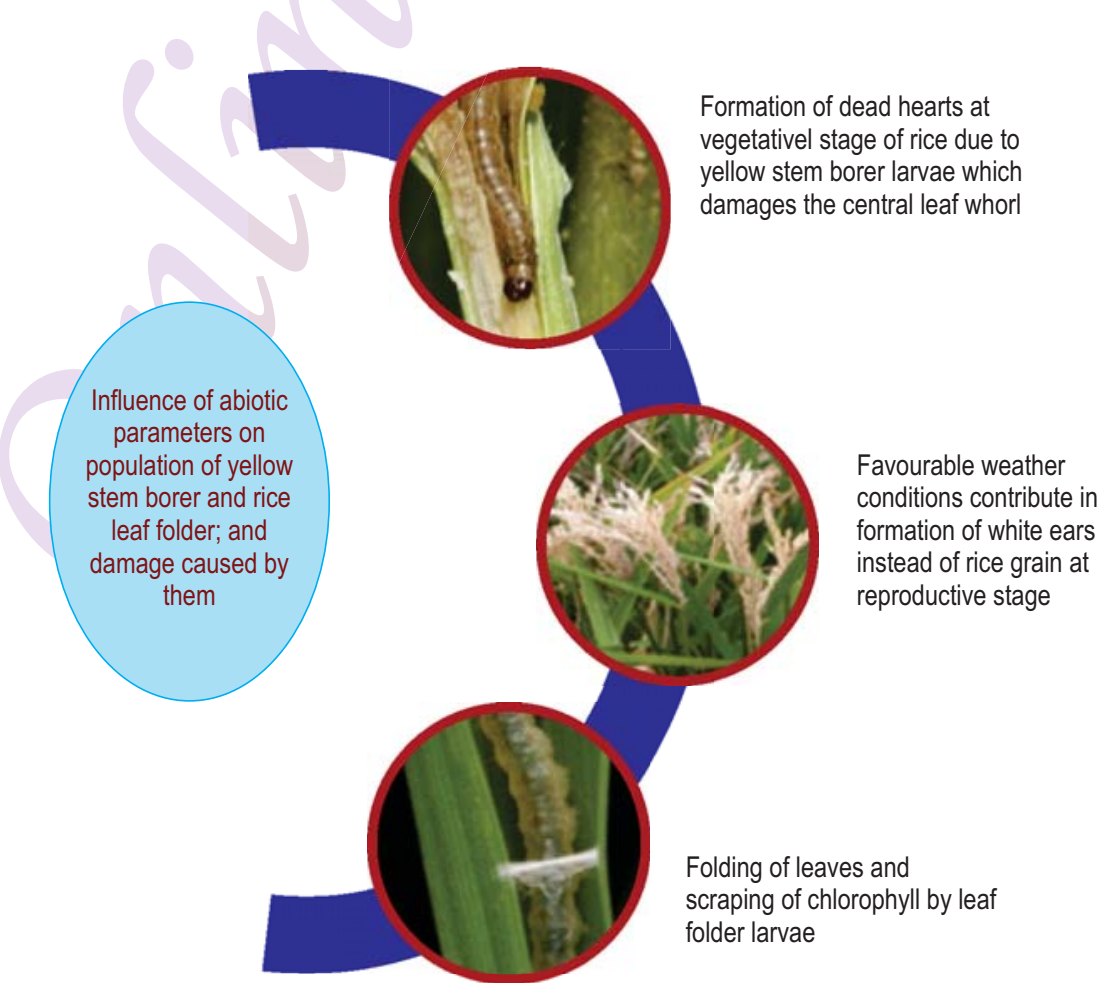




\section{Introduction}

Rice, is one of three principal food crops in the world, providing food for nearly half of the global population (Anonymous, 2004). Almost $90 \%$ of rice is grown and consumed in Asia. It is used as a food for more than two billion people in developing countries of Asia (Khush and Brar, 2002).

The rice plant is subject to attack by more than 100 species of insects; 20 of them can cause economic damage. The yellow stem borer, Scirpophaga incertulas (Walker) has assumed the number one pest status and attack the crop at all the stages. Among the borers; yellow stem borer is distributed throughout India and regarded as most dominating and destructive pest species causing about $25-30 \%$ reduction in yield and it causes 27.34\% losses annually (Pasulu et al., 2002, Catling et al., 1987 and Prasad et al., 1988). Caterpillar of yellow stem borer bores into the stem and feed inside. As a result central shoot withers and produces dead heart and white ear heads at the harvest stage which can lead to the complete failure of the crop (Karthikeyan and Purushothaman, 2000). The rice leaf folder Cnaphalocrocis medinalis (Guenee), so far, is considered as a minor pest, has assumed major pest status during the last two decades (Nanda et al., 2000). Changes in the physical environment, cultural practices, multiple cropping patterns, reduced genetic variability of high yielding rice varieties, application of high levels of nitrogenous fertilizer and prophylactic use of pesticides are the major reasons for rice leaf folder problem. The larvae fold the tender leaves and scrape the green tissues of the leaves and cause scorching and leaf drying. Each larva is capable of destroying several leaves by its feeding. Severe infestation of this pest may lead to 60 to $70 \%$ leaf damage (Kushwaha and Singh, 1986). It is reported that under favorable conditions RLF affects the crop adversely resulting in severe loss (Anuj et al., 1999)

Weather plays an important role in crop growth, as well as development of pest and diseases. Abiotic factors viz., temperature, light, moisture etc., have a direct influence on insect distribution and development. Wind and rain are importat not only for survival, but also for disposal of insect population (Saxena and Murty, 2014). Hence, studies on environmental effect on pest population helps in planning need based application of insecticides as it clearly reveals the insect's peak activity, as well as insect free periods during crop growth. The studies on seasonal occurrence are envisaged to have an insight into the predisposing ecological factors of the pest.

\section{Materials and Methods}

A experiment was conducted during the kharif season of 2013-14, at the Agricultural Research Farm, B.H.U., Varanasi $\left(24^{\circ} 56^{\prime} \mathrm{N}\right.$ to $25^{\circ} 35^{\prime} \mathrm{N}$ Latitude and $82^{\circ} 14^{\prime} \mathrm{E}$ to $83^{\circ} 24^{\prime} \mathrm{E}$ Longitude). The rice variety tested during this experiment was Swarna sub-1. It is a flood tolerant version of the popular mega variety Swarna (MTU 7029) in eastern India. It was developed at International Rice Research Institute, Philippines. It has a good grain yield and grain quality. It can survive under full submergence for more than two weeks (IRRI, 2013). A bulk plot of $100 \mathrm{~m}^{2}$ was raised in the main farm area so as to study the population buildup of the pests under study. The pest population was recorded in this unprotected plot at 7 days interval from the occurrence or initiation of pest infestation and was continued up to maturity. The incidence of pests was recorded on 10 randomly selected hills. Weather data were recorded simultaneously from the metrological observatory available at Banaras Hindu University and correlated with the occurrence of the pest population. To work out the relationship between the occurrence of the pest and weather parameters correlation method was adopted. Infestations of yellow stem borer counts were taken on number of dead hearts/white ears and total number of tillers/panicle from 10 randomly selected hills. The per cent incidence (dead heart/ white ears) was calculated as follows:

Percent Incidence $=\frac{\text { Number of dead hearts } / \text { white ears } \times 100}{\text { Total number of tillers/ panicles }}$

The damaged of RLF leaves and total leaves from 10 randomly selected hills were observed in each plot. The percentage of leaf damage was calculated as follows :

Percent Incidence $=\frac{\text { Number of damaged leaves } \times 100}{\text { Total number of leaves }}$

The observations were recorded by sweeping method; using insect colleting net. Five sweeps were made in each treatment and the number of nymphs and adults caught were counted. The total count from three replications was averaged and expressed as number of insects per 5 sweeps basis. The ANOVA of data recorded during the experiment was made for the insect pests under study and the calculated ' $F$ ' was compared with tabulated ' $F$ ' at $5 \%$ level of significance. Significant difference between treatments was judged by $C D$ at $5 \%$ level of significance

\section{Results and Discussion}

The abiotic parameters are known to have direct impact on insect population dynamics through modulation of developmental rates, survival, fecundity, voltinism and dispersal (Karuppaiah and Sujayanad, 2012). During present investigation, the record of yellow stem borer population indicated that abiotic factors (i.e. rainfall, temperature and relative humidity) play an important role an regulating the yellow stem borer population on rice plants during kharif season. 


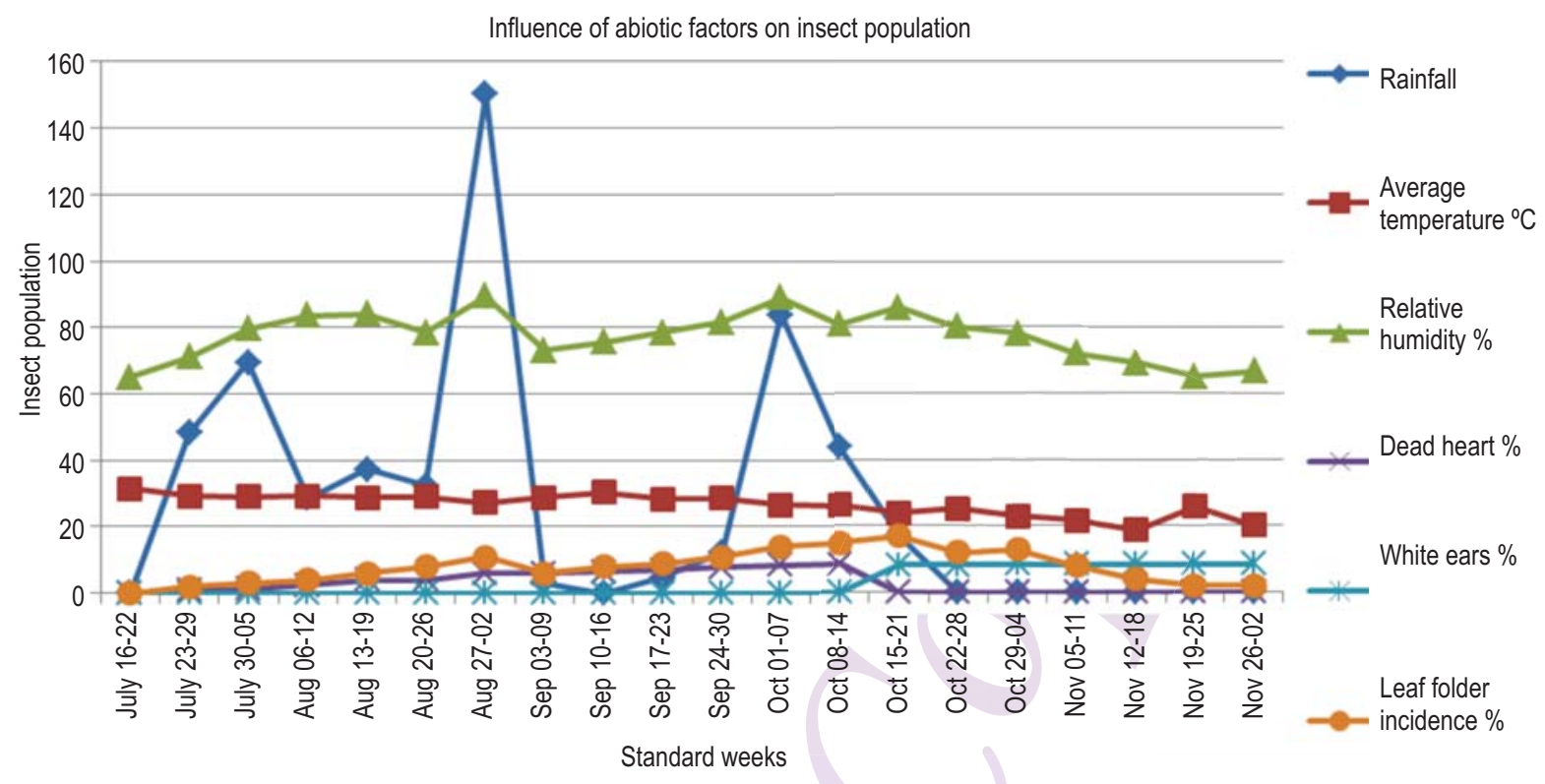

Fig. 1 : Seasonal incidence of yellow stem borer and rice leaf folder on rice during kharif 2013

Table 1 : Influence of abiotic factors on population of YSB and RLF on kharif rice (2013)

\begin{tabular}{|c|c|c|c|c|c|c|c|c|c|c|}
\hline \multirow[t]{2}{*}{$\begin{array}{l}\text { Month \& } \\
\text { Date }\end{array}$} & \multirow[t]{2}{*}{$\begin{array}{l}\text { Rainfall } \\
(\mathrm{mm})\end{array}$} & \multicolumn{3}{|c|}{ Temperature $\left({ }^{\circ} \mathrm{C}\right)$} & \multicolumn{3}{|c|}{ Relative humidity (\%) } & \multicolumn{2}{|c|}{$\begin{array}{l}\text { Yellow stem borer } \\
\text { (No. of dead hearts / } \\
\text { white ears / } 10 \text { hills }\end{array}$} & \multirow[t]{2}{*}{$\begin{array}{l}\text { Rice leaf } \\
\text { folder (larvae/ } \\
10 \text { hills) }\end{array}$} \\
\hline & & MAX & MIN & Average & Morning & Evening & Average & $\mathrm{DH}^{*}$ & $W E^{* *}$ & \\
\hline Jul 16-22 & 0 & 34.8 & 28.3 & 31.55 & 83 & 67 & 65 & 0 & - & 0 \\
\hline $23-29$ & 48.2 & 32.2 & 26.3 & 29.25 & 86 & 77 & 71 & 0.8 & - & 2 \\
\hline $30-05$ & 69.5 & 32.5 & 25.5 & 29 & 84 & 75 & 79.5 & 1.33 & - & 3 \\
\hline Aug 06-12 & 28.6 & 32.5 & 26 & 29.25 & 91 & 76 & 83.5 & 2.45 & - & 4 \\
\hline $13-19$ & 37.4 & 31.8 & 25.7 & 28.75 & 88 & 80 & 84 & 4 & - & 6 \\
\hline $20-26$ & 32.3 & 32.1 & 26.2 & 29.15 & 83 & 74 & 78.5 & 4.1 & - & 8 \\
\hline $27-02$ & 150.3 & 28.7 & 25.7 & 27.2 & 92 & 87 & 89.5 & 6 & - & 11 \\
\hline Sep 03-09 & 3.2 & 32.5 & 25.3 & 28.9 & 80 & 66 & 73 & 6.1 & - & 6 \\
\hline $10-16$ & 0 & 33.7 & 26.9 & 30.3 & 85 & 66 & 75.5 & 6.5 & - & 8 \\
\hline $17-23$ & 4.6 & 31.6 & 25.3 & 28.45 & 81 & 76 & 78.5 & 6.91 & - & 9 \\
\hline $24-30$ & 12.2 & 31.6 & 25.5 & 28.55 & 86 & 77 & 81.5 & 7.77 & - & 11 \\
\hline Oct 01-07 & 83.9 & 28.8 & 24.3 & 26.55 & 93 & 85 & 89 & 8.56 & - & 14 \\
\hline $08-14$ & 44 & 29.1 & 23.8 & 26.45 & 84 & 78 & 81 & 8.59 & - & 15 \\
\hline $15-21$ & 17 & 26.7 & 21.1 & 23.9 & 92 & 80 & 86 & - & 8.33 & 17 \\
\hline $22-28$ & 0 & 29.6 & 21.1 & 25.35 & 88 & 72 & 80 & - & 8.35 & 12 \\
\hline $29-04$ & 0 & 28.6 & 17.3 & 22.95 & 80 & 76 & 78 & - & 8.36 & 13 \\
\hline Nov 05-11 & 0 & 27.7 & 15.5 & 21.6 & 84 & 60 & 72 & - & 8.37 & 8 \\
\hline $12-18$ & 0 & 26.2 & 11.5 & 18.85 & 90 & 48 & 69 & - & 8.4 & 4 \\
\hline $19-25$ & 0 & 26.7 & 25 & 25.85 & 89 & 41 & 65 & - & 8.42 & 2 \\
\hline $26-02$ & 0 & 26.4 & 13.7 & 20.05 & 87 & 46 & 66.5 & - & 8.44 & 2 \\
\hline
\end{tabular}

*DH: Dead hearts; **WE: White ears

In the present study, yellow stem borer appeared in rice crop during (30th standard week) of July (i.e. 24 to 26 days after transplanting). The highest percent incidence of dead heart was seen by end of September onwards (i.e. standard week 40).
Thereafter, at the panicle initiation stage, a sharp shoot in the development of white ears is observed by $\left(44^{\text {th }}\right.$ standard week) of October. These white ears remain in the field till the harvesting of the crop without showing any further increase in their percent. 
Table 2: Correlation ( $r$ ) between pest population and abiotic factors in rice during Kharif 2013

\begin{tabular}{|c|c|c|c|c|c|c|c|c|}
\hline \multicolumn{9}{|c|}{ Weather parameter } \\
\hline & & Rainfall & & ive humid & & & perature $\left({ }^{\circ} \mathrm{C}\right.$ & \\
\hline \multicolumn{2}{|c|}{ Insect pests } & $(\mathrm{mm})$ & Morning & Evening & Average & Maximum & Minimum & Average \\
\hline Yellow & $\% \mathrm{DH}$ & 0.086 & 0.110 & 0.296 & $0.542^{*}$ & $-0.650^{* *}$ & $-0.699^{* *}$ & $-0.701^{* *}$ \\
\hline stem borer & $\% W E$ & 0.482 & 0.047 & $0.916^{* *}$ & $0.945^{*}$ & $0.648^{*}$ & 0.256 & 0.389 \\
\hline Leaf folder & 0.209 & 0.150 & $0.572^{* *}$ & $0.721^{* *}$ & -0.301 & -0.064 & -0.157 & \\
\hline
\end{tabular}

${ }^{*}$ Correlation is significant at 0.01 level; ${ }^{*}$ Correlation is significant at 0.05 level

Correlation coefficient between different weather parameters and per cent incidence revealed that, mean temperature recorded significant negative correlation with $\%$ dead heart and $\%$ white ears with a correlation coefficient of $(r=-0.701)$ and $(r=0.389)$ respectively (Table 2 ). Mean relative humidity showed a positive correlation with per cent dead heart $(r=0.542)$ and percent white ears $(r=0.945)$ (Table 2). Positive correlation was observed between total rainfall and percent dead hearts $(r=0.086)$ and white ears $(\mathrm{r}=0.047)$ formed due to yellow stem borer (Table 2 ).

The rainfall and relative humidity were positively correlated to the population of yellow stem borer, whereas average temperature was negatively correlated to the percent incidence. With view of Kakde and Patel (2014), a positive correlation between the incidence of the pest and relative humidity. Adiroubane and Raja (2013), reported a negative correlation of dead heart $\%$ with temperature. Pre sent findings are in line with the results of Justin and Preetha (2013), who reported the occurrence of the pest, peaked during SeptemberOctober. Hugar et al. (2010) reported that infestation of yellow stem borer had a negative correlation with maximum temperature in kharif rice. The present findings showed that the rainfall had an insignificant positive correlation with percent dead hearts and white ears. While relative humidity was significantly and positively correlated with the percent dead heart and white ears. The average temperature was significantly and negatively correlated with percent dead heart, while white ears were insignificantly, positively correlated

The incidence of rice leaf folder was severe from last week of September to last of October (i.e., standard week $47^{\text {th }}$ ). Similar findings were reported by Patel et al., (2011) who found that July sown crop had maximum infestation of $58.3 \%$ as against $2.2 \%$ in the month of October. The population of leaf folder decreased as the crop reached the harvesting stage around (i.e., standard week 40 to 44) third week of November. Similar findings have been reported by Patel et al. (2011) for larval incidence of leaf folder. A correlation coefficient between different weather parameters and percent incidence revealed that it was significantly negatively correlated with mean temperature recorded with a correlation coefficient of $r=-0.157$ (Table 2). Mean relative humidity had a positive correlation with $\%$ incidence $r=0.721$ (Table 2). Moreover, a positive correlation was observed between total rainfall and \% incidence of rice leaf folder $r=0.209$ (Table 2).

The present study showed that the incidence of RLF occurred after four weeks of transplantation. Rainfall was insignificantly and positively correlation with percent incidence. Xu Ruique et al. (1999) reported that generations of C. medinalis were positively correlated with the number of rainy days and amount of rainfall. While relative humidity was significantly and positively correlated with the percent incidence. The average temperature was insignificantly and negatively correlated with per cent incidence of leaf folder.

The population of yellow stem borer appeared on crop 2330 days after transplanting at 30th standard week of July. However, maximum infestation was observed at 44th standard week of October. The population fluctuation was correlated with abiotic factors (rainfall, temperature and relative humidity) which showed that average temperature was negatively, whereas rainfall and relative humidity were positively correlated with population of yellow stem borer.

The population of rice leaf folder appeared on crop 30 days after transplanting at $31^{\text {th }}$ standard week of July. However, maximum infestation was observed on $41^{\text {th }}$ to $44^{\text {th }}$ standard week of October. The population fluctuation was correlated with abiotic factors (rainfall, temperature and relative humidity), which showed that temperature was negatively whereas rainfall and relative humidity were positively correlated with population of RLF. Recently, Nirala et al. (2015) reported that RLF was positively correlated with rainfall and average relative humidity in midland normal transplanted rice ecosystem.

The growth and survival of insect species might get adversely affected beyond the favorable range of temperature and humidity (Reji et al., 2014), hence studies on impact of abiotic parameters against a pest gives a deeper insight and understanding in formulating better management practices.

\section{Acknowledgment}

The authors are grateful to the head, Department of Entomology and Agricultural Zoology, Institute of Agricultural 
Sciences, Banaras Hindu University for providing the necessary help required during the experiment.

\section{References}

Adiroubane, D. and K. Raja: Influence of weather parameters on the occurrence of rice yellow stem borer, Scirpophaga incertulas (Walker). J. Rice Res., 3, 5-9 (2013).

Anonymous: Food and Agriculture Organization of the United Nations. The state of food security in the world, p. 30-31 (2004).

Anuj, B., P. Saxena and A. Bhatnagar: Environmental correlations of population buildup of rice pests through light trap catches. Oryza, 36, 241-5 (1999).

Catling, H.D., Z. Islam and R. Pattrasudhi: Assessing yield losses in deep water rice due to yellow stem borer, S.incertulas in Bangaladesh and Thailand. Crop Prot. J., 6, 20-27 (1987).

Chandramohan, N., S. Sankaranarayan and S. Jayaraj: Influence of sowing of rice on the incidence of four major pests. Mad. Agric. J., 64, 573-576(1976).

Hugar, S.V., V. Hosamani, B.C. Hanumanthaswamy and S. Pradeep: Influence of weather factors on the infestation of yellow stem borer,Scirpophaga incertulas Walker in aerobic rice. Asian J. Environ. Sci., 4, 151-154 (2010).

Justin, C.G.L. and G. Preetha: Seasonal incidence of rice yellow stem borer, Scirpophaga incertulas (Walker) in Tamil Nadu. Indian J. Entomol., 75, 109-112 (2013).

Kakde, A.M., and K.G. Patel: Seasonal Incidence of rice yellow stem borer (Scirpophaga incertulas Wlk.) in relation to conventional and sri methods of planting and its correlation with weather parameters. IOSR J. Agric. Vete. Sci., 7, 05-10 (2014).

Karthikeyan, K. and S. M. Purushothaman: Efficacy of carbosulfan against rice yellow stem borer, Scirpophaga incertulas Walker (Pyralidae: Lepidoptera). Ind. J. Plant Protec., 28, 212-214 (2000).

Karuppaiah, V. and G.K. Sujayanad: Impact of climate change on population dynamics of insect pests. World J. Agricult. Sci., 8, 240$246(2012)$.

Khush, G.S. and D.S. Brar: Biotechnology for rice breeding: Progress and Potential impact. In: Proceeding of the 20th Session of the International Rice Commission (23th-26thJuly, Bangkok, Thailand) (2002). Internet: http://www.fao.org/ docrep/006/ Y4751E/y4751e04.htm.

Kushwaha, K.S. and R. Singh: Leaf folder, Cnaphalocrocis medinalis damage in scented and non-scented rice varieties under field conditions in Haryana, India. Agri. Sci. Digest., 6, 12-13 (1986).

Nanda, U.K., G.K. Mahapatro, A. Sahoo and S.C. Mahapatra: Rice leaffolder: Integrated neem derivatives in its management. Pestology, 24, 31-34 (2000).

Nirala, Y.S., C.M. Sahu, S.K. Ghirtlahre, K.L. Painkra and G. Chandraka: Studies on seasonal incidence of leaf folder, Cnaphalocrocis medinalis in Midland Sri and normal transplanted rice ecosystem. Inter. J. Tro. Agric., 33, 547-551 (2015).

Pasulu, I.C., N.V. Krishnaiah, G. Kotti and N.R.G. Varma: IPM in rice mitr. pp. 45-55 (2002).

Patel, H. N., R. V. Kadu and S. A. Landge: Study on effect of different botanicals against rice leaf folder, Cnaphalocrocis medinalis Guen. and Pelopidas mathias Fb. Inter. J. Plant Prot., 4, 148-152 (2011).

Prasad, S.S., P.K. Gupta and R.B. Singh: Yield losses in floating rice caused by stem borers. Int. Rice Res. News, 13, 38 (1988).

Reji, G., S. Chander and K. Kamble: Predictive zoning of rice stem borer damage in southern India through spatial interpolation of weatherbased models. J. Environ. Biol., 35, 923-928 (2014).

Saxena, S. and N.S. Murty: Weather based model development for outbreak of mustard aphid (L. erysimi., Kalt) using artificial neural network. The Ecoscan, 8, 47-52 (2014).

$\mathrm{Xu}, \mathrm{R} ., \mathrm{X}$. Zeng and R.F. Huang: The relationship between the abundance of the most harmful generation of Cnaphalocricis medinalis (Guenee) and rainfall. J. Fiji. Aca. Agric. Sci., 14, 23-25 (1999). 